\title{
Metode Simulated Annealing untuk Optimasi Penjadwalan Perkuliahan Perguruan Tinggi
}

\author{
Wiktasari ${ }^{\mathrm{a},},{ }^{*}$ Jatmiko Endro Suseno ${ }^{\mathrm{b}}$ \\ ${ }^{a}$ Universitas Islam Sultan Agung Semarang \\ 'Jurusan Fisika, Fakultas Sains dan Matematika, Universitas Diponegoro
}

Naskah Diterima : 21 Mei 2016; Diterima Publikasi : 11 Oktober 2016

DOI: $10.21456 /$ vol6iss2pp133-143

\begin{abstract}
Course scheduling an assignment of courses and lecturers in the available time slots involving certain restrictions. Simulated annealing is a heuristic method can be used as search method and provide acceptable solutions with good results. The research aims to make scheduling courses at the college using simulated annealing using five variables data that lecturer courses, the time slot is comprised of the day and the time period and class room. The research has two objective functions to be generated, the first is the assignment of a lecturer on courses that will be of teaching, second lecturers and their assignment course on the time slot and the room available. The objective function is calculated by taking into account the restrictions involved to produce the optimal solution. The validation is performed by testing to simulated annealing method with an varian average of $77.791 \%$ of the data variance can reach a solution with a standard deviation of 3.931509. In this research given the method of solution in the use of the remaining search space to be reused by the data that is unallocated.
\end{abstract}

Keywords: Scheduling; Timetabling; Simulated annealing; Heuristic; Objective function; Constraint

\begin{abstract}
Abstrak
Penjadwalan kuliah merupakan penugasan mata kuliah dan dosen pengampu pada slot waktu yang tersedia dengan melibatkan batasan tertentu. Simulated annealing merupakan salah satu metode heuristic yang dapat digunakan sebagai metode pencarian dan memberikan solusi yang dapat diterima dengan hasil yang baik. Penelitian ini bertujuan untuk membuat penjadwalan mata kuliah pada perguruan tinggi menggunakan metode simulated annealing dengan lima variabel data yaitu dosen, mata kuliah, slot waktu yang terdiri dari hari dan waktu periode dan variabel ruang. Penelitian ini memiliki dua fungsi tujuan yang akan dihasilkan, pertama adalah penugasan dosen pada mata kuliah yang akan diampu, kedua penugasan mata kulia beserta dosen pada slot waktu dan ruang yang tersedia. Fungsi tujuan dihitung dengan memperhatikan batasan yang terlibat untuk menghasilkan solusi yang optimal. Validasi dilakukan dengan uji coba terhadap metode simulated annealing dengan menghasilkan rata-rata varian sebesar 77,791\% data dapat mencapai solusi dengan standar deviasi sebesar 3.931509. Pada penelitian ini diberikan metode solusi dalam penggunaan ruang pencarian yang tersisa untuk dapat digunakan kembali oleh data yang belum teralokasikan.
\end{abstract}

Kata kunci: Penjadwalan, Timetabling, Simulated annealing, Heuristic, Objective aunction, Batasan

\section{Pendahuluan}

Penjadwalan perguruan tinggi menjelaskan dimana dan kapan sumber daya manusia dan sumber daya pendukung ditempatkan pada waktu yang telah ditentukan yang terdiri dari mahasiswa, dosen dan staff pendukung sedangkan sumber daya ruang terdiri dari kelas, ruang dan laboratorium (Chamber, 1998, Basir et al., 2013).

Masalah penjadwalan (timetabling) mata kuliah perguruan tinggi termasuk kedalam permasalahan

*) Penulisa korespondensi: wiktasari@unissula.ac.id penjadwalan yang harus diselesaikan pada setiap semester secara terus menerus, alokasi pada slot waktu dan ruang dengan mempertimbangkan hard constraints dan soft constraints. Penjadwalan mata kuliah perguruan tinggi terdiri dari hard constraint merupakan batasan yang harus dihindari dengan berbagai kondisi dan soft constraint yang merupakan batasan yang sedapat mungkin dihindari (Babei et al., 2015).

Penjadwalan universitas dapat diperlakukan sebagai permasalahan optimasi yang bertujuan untuk optimasi objective function. Objective function dapat 
berupa kepuasan preferensi yang dimiliki dosen dalam memilih slot waktu (timeslot) dalam sehari atau seminggu (Daskalaki et al., 2004). Salah satu metode yang digunakan untuk permasalahan optimasi adalah simulated annealing (SA). SA telah digunakan untuk permasalahan optimasi kombinatorial. SA merupakan metode dengan pendekatan pencarian solusi yang random (Mu et al., 2015).

Metode yang dipilih simulated annealing dapat diterapkan pada berbagai jenis masalah timetabling atau penjadwalan dengan menggunakan berbagai macam hard constraint dan soft constraint didapatkan fitness function yang baik atau optimum (Basir, 2013)

Penelitian ini bertujuan untuk membuat penjadwalan mata kuliah pada perguruan tinggi menggunakan metode simulated annealing dengan lima variabel data yaitu dosen, mata kuliah, slot waktu yang terdiri dari hari dan waktu periode dan variabel ruang. Manfaat yang diharapkan dari hasil penelitian ini adalah dapat memaksimalkan penggunaan sumber daya yang terlibat dalam proses penjadwalan sehingga menghasilkan jadwal kuliah lebih baik.

\section{Kerangka Teori}

\subsection{Model Permasalahan Penjadwalan Mata Kuliah}

Penjadwalan merupakan alokasi sumber daya yang tersedia dari waktu ke waktu dalam menjalankan tugas tertentu untuk mencapai tujuan tertentu (Kopanosa et al., 2012). Jadwal tidak hanya terdiri dari daftar operasi tetapi juga dapat berisi informasi mengenai beberapa operasi yang mungkin dilaksanakan secara bersamaan dan beberapa operasi perlu diselesaikan sebelum operasi lain dimulai. Penjadwalan dan pembebanan merupakan kunci efisiensi dalam produksi dan operasi adalah kemampuan untuk menyusun jadwal secara efektif (Yamit, 2011).

Penjadwalan mata kuliah perguruan tinggi merupakan penugasan himpunan mata kuliah kedalam slot waktu yang tersedia dengan memperhatikan batasan. Optimasi himpunan dengan beberapa kriteria variabel sebagai input akan menghasilkan keputusan dengan memperhatikan batasan yang terkait untuk menghasilkan jadwal kuliha. Model dataset penjadwalan mata kuliah adalah sebagai berikut (Fong et al., 2014):

Tujuan yang diharapkan dari penjadwalan adalah dapat menjadwalkan semua mata kuliah $\mathrm{C}$ kedalam slot waktu yang tersedia dengan menggunakan ruang kelas yang tersedia dengan memperhatikan semua hard constraint.

\subsection{Formulasi Simulated Annealing}

Terdapat beberapa kebutuhan dalam formulasi optimasi metode SA yaitu (Kalivas, 1995):

1. Melakukan spesifikasi nilai tunggal dari objective function baik dalam bentuk ekspresi tertutup maupun sebuah prosedur untuk komputasi.

2. Mendeskripsikan variabel (argumen dari objective function) dan daerah dimana akan dilakukan pencarian solusi atau yang disebut dengan constraint. Variabel yang digunakan adalah variabel input yang terkait dengan variabel dalam pengambilan keputusan.

3. Mendefinisikan tetangga dari variabel. Tetangga ini harus bernilai kecil dibanding dengan nilai objective function dari tetangga-tetangga terdekatnya.

4. Membuat sebuah prosedur yang menghasilkan langkah-langkah pseudo-random untuk melewati tetangga.

5. Membuat kriteria perhentian langkah-langkah random yang dibuat pada langkah 4. Langkah perhentian dibedakan menjadi dua kasus, yaitu: a) Nilai optimal objective function dan lokasi yang akan ditentukan telah diketahui sebelumnya; b) Baik nilai optimal maupun lokasinya tidak diketahui.

\subsection{Algoritma Simulated Annealing}

SA memiliki kemampuan untuk keluar dari lokal optimum berdasarkan aturan penerimaan solusi kandidat. Aturannya adalah jika nilai objective function pada solusi sekarang lebih kecil dibanding solusi dulu, maka solusi sekarang diterima. T adalah parameter pengendali temperatur. Parameter $\mathrm{T}$ merupakan pengendali ruang pencarian atau ruang penempatan partikel pada proses pendingingan. Flowchart algoritma SA dapat dilihat pada Gambar (Chibante, 2010).

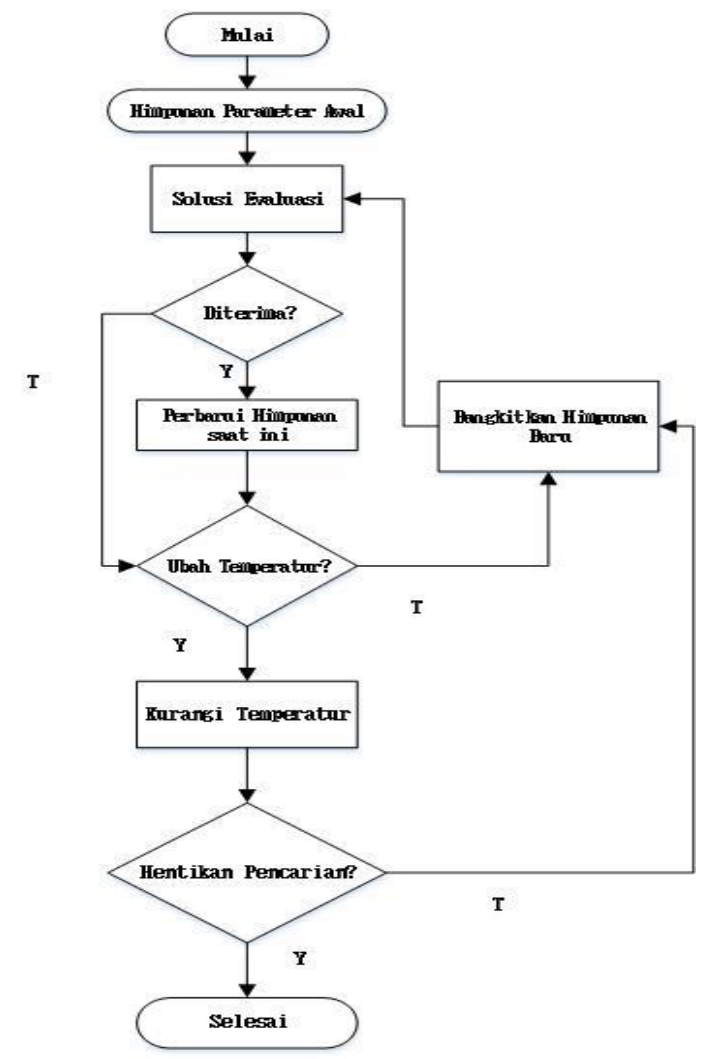

Gambar 1. Flowchart Algoritma SA 
1. Populasi Awal

Menentukan definisi dari nilai parameter yang akan digunakan.

2. Temperatur Awal

Temperatur atau suhu pada SA digunakan sebagai parameter pengendali yang harus didefinisikan secara hati-hati pada saat penentuan populasi awal.

3. Mekanisme Gangguan

Metode yang berfungsi untuk membuat solusi baru yang berasal dari solusi sekarang yiatu melakukan eksplorasi tetangga dari solusi sekarang dan melakukan perubahan pada solusi sekarang. Pada umumnya SA digunakan dalam optimasi bilangan integer untuk permasalahan kombinatorial.

4. Objective Function

Objective function merupakan ekspresi yang berhubungan dengan parameter dengan beberapa property untuk diminimasi atau dimaksimasi.

5. Jadwal Pendinginan

Jadwal pendinginan pada umumnya digunakan dalam aturan geometrik untuk variasi temperature:

$$
T_{i+1}=s T_{i}
$$

dengan $s<1$.

6. Kriteria Akhir

Terdapat beberapa metode untuk pengendali perhentian dari sebuah algoritma, yaitu:

a. Jumlah maksimum perulangan

b. Nilai minimum temperatur

c. Nilai minimum objective function

d. Nilai minimum kecepatan penerimaan.

Ada 6 tahapan algoritma SA yang digunakan untuk menyelesaikan permasalahan optimasi (Kalivas, 1995):

1. Memilih titik awal $X_{0}$ secara acak atau ditentukan terlebih dahulu berdasar pengetahuan dari permasalahan yang dihadapi dan menentukan nilai yang sesuai dengan objective function $\phi\left(X_{0}\right)$;

2. Memilih langkah acak $s \in X$;

3. Pada titik $X_{k}$ hitung perubahan sementara nilai objective function

$$
\Delta f \leftarrow f\left(s^{\prime}\right)-f(s)
$$

4. Memeriksa kriteria perhentian, jika memenuhi berhenti, sebaliknya;

5. Untuk $\Delta f \leq 0$ tentukan $X_{k+1}+\Delta f$, kembali ke langkah (2);

6. Untuk $\Delta f>0$ periksa $\exp (-\beta \Delta f)$ pilih nilai acak $\rho, 0<\rho<1$, dari beberapa spesifikasi distribusi pada $[0,1]$ kemudian bandingkan :

a. Jika $\exp (-\beta \Delta f) \leq \rho$ kembali ke langkah (5)

b. Jika $\exp (-\beta \Delta f)>\rho$ kembali ke langkah (2)

\subsection{Constrain dalam Penjadwalan Kuliah}

Dalam penjadwalan mahasiswa dan penjadwalan mata kuliah terdapat beberapa hard constraint dan soft constraint yaitu (Cacchiani dkk., 2013):

1. Hard constraint

a. Semua dosen untuk setiap mata kuliah harus dijadwalkan.

b. Setiap dosen tidak dapat mengajar lebih dari satu mata kuliah dalam satu waktu periode.

c. Setiap ruang tidak dapat memiliki dosen lebih dari satu dalam satu waktu.

d. Waktu periode yang tidak ditawarkan tidak dapat digunakan dalam penjadwalan.

2. Soft constraint

a. Jumlah kelas harus dijaga sesedikit mungkin dan kelas sebisa mungkin harus memenuhi kapasitas.

b. Setiap kelas memiliki jumlah mahasiswa maksimum.

\subsection{Pernyataan dan Formulasi Permasalahan}

1. Himpunan

Himpunan yang digunakan dalam pemodelan untuk permasalahan penjadwalan terdiri dari himpunan dosen, mata kuliah, mahasiswa, hari, slot waktu dan mata kuliah dengan dossen pengampu dapat dinotasikan sebagai berikut di bawah ini (Gunawan et al., 2012):

I himpunan semua dosen

$J \quad$ himpunan semua mata kuliah

$H \quad$ himpunan semua mahasiswa

$L \quad$ himpunan semua hari yang tersedia

M himpunan semua slot waktu (timeslot) yang tersedia

$j_{i} \quad$ himpunan semua mata kuliah yang dapat diajar oleh dosen $i, J_{i} \subset J(\forall i \in I)$

2. Parameter Input

Parameter input yang digunakan dalam pemodelan untuk permasalahan penjadwalan dapat ditunjukkan sebagai berikut :

$N_{i} \quad$ maksimum beban dosen

$C \quad$ jumlah ruang kelas yang tersedia per

$H_{j} \quad$ jumlah slot waktu yang dibutuhkan per

mata kuliah $j(i \forall \in J)$

$P C_{i j} \quad$ nilai preferensi yang diberikan untuk dosen $i$ untuk ditugaskan mengajar mata kuliah $\mathrm{j}(\forall i \in I, \forall j \in J)$

$P T_{\text {ilm }} \quad$ nilai preferensi yang diberikan oleh dosen $i$ untuk ditugaskan mengajar dalam sehari dan waktu periode $\mathrm{m}(\forall i \in$ $I, \forall m \in M)$.

$L T_{j} \quad$ jumlah minimum dosen yang dapat mengampu mata kuliah $\mathrm{j}(\forall i \in J)$

$U T_{j} \quad$ jumlah maksimum dosen yang dapat mengampu mata kuliah j $(\forall i \in J)$ 
3. Variabel Keputusan

Variabel keputusan yang digunakan dalam pemodelan untuk permasalahan penjadwalan dapat ditunjukkan sebagai berikut :

$X_{i j l m}=1 \quad$ jika dosen $i$ mengajar mata kuliah $j$ pada hari $l$ pada slot waktu $m$; sebaliknya 0 maka

$(\forall i \in I, \forall j \in J, \forall l \in L, \forall m \in M)$

$Y_{i j l}=1 \quad$ jika dosen $i$ mengajar mata kuliah $j$ pada hari $l$; sebaliknya 0 maka $(\forall i \in I, \forall j \in$ $J, \forall l \in L)$

$U_{i j l m}=1 \quad$ jika dosen $i$ mengajar mata kuliah $j$ pada hari $l$ dengan mulai pada slot waktu $m$; sebaliknya 0 maka $(\forall i \in I, \forall j \in J, \forall l \in$ $L, \forall m \in M$ )

$P_{i j}=1 \quad$ jika dosen i mengajar mata kuliah j; 0 maka $(\forall i \in I, \forall j \in J)$

$L_{i} \quad$ jumlah mata kuliah yang diajar oleh dosen $i(\forall i \in I)$

$V_{i} \quad$ jumlah mata kuliah yang diajar oleh dosen $i$ setiap hari $(\forall i \in I)$

\section{Objective Function:}

[MataKuliah - Dosen] Max

$$
=\sum_{i \in I} \sum_{j \in J} P C_{i j} P_{i j}
$$

[Plotting - SlotWaktu]Max

$$
=\sum_{i \in I} \sum_{j \in J} \sum_{l \in L} \sum_{m \in M} P T_{i l m} X_{i j l m}
$$

Persamaan (2.1) merupakan objective function yang akan dimaksimalkan, yang terdiri dari penjumlahan nilai preferensi total untuk pengusana mata kuliah j ke dosen i kemudian persamaan (2.2) adalah objective function 2 yaitu penugasan mata kuliah $\mathrm{j}$ dengan dosen pengampu $i$ pada hari $l$ pada slot waktu $(m \in M)$.

$$
\begin{aligned}
& 1 \leq \sum_{j \in J} P_{i j} \leq N_{i}(i \in I) \\
& L T_{j} \leq \sum_{i \in I} P_{i j} \leq U T_{j}(j \in J) \\
& \sum_{m \in M} X_{i j l m}=Y_{i j l} H_{j}(i \in I, j \in J, l \in L) \\
& \sum_{j \in J}^{j} X_{i j l m} \leq 1(i \in I, l \in L, m \in M) \\
& \sum_{i \in I} \sum_{j \in J} X_{i j l m} \leq C(m \in M) \\
& \sum_{i \in I} \sum_{l \in L} Y_{i j l}=1(j \in J) \\
& X_{i j l m}=0\left(i \in I, j \notin J_{i}, m \in M\right) \\
& \sum_{j \in J} \sum_{l \in L} Y_{i j l}=L_{i} \quad(i \in I) \\
& \sum_{j \in J} Y_{i j l} \leq V_{i}(i \in I, l \in L) \\
& X_{i j l m} \in\{0,1\}(i \in I, j \in J, l \in L, m \in M) \\
& Y_{i j l} \in\{0,1\}(i \in I, j \in J, l \in L)
\end{aligned}
$$

$$
\begin{gathered}
U_{i j l m} \in\{0,1\}(i \in I, j \in J, l \in L, m \in M) \\
P_{i j} \in\{1,0\}(i \in I, j \in J) \\
L_{i} \in Z^{+}(i \in I) \\
V_{i} \in Z^{+}(i \in I)
\end{gathered}
$$

Pers. (2.3) dan pers (2.4) menunjukkan objective function yang akan dimaksimasi, merupakan penjumlahan nilai preferensi yaitu penugasan dosen ke mata kuliah, pemilihan hari dan slot waktu dosen untuk mengajar dan penempatan slot waktu untuk mata kuliah dalam dalam kurikulum yang sama. Pers. (2.5) membatasi jumlah mata kuliah yang dapat diampu oleh dosen, dosen paling tidak mengampu satu mata kuliah.

Pers. (2.6) batasan jumlah minimum dan maksimum dosen yang mengampu mata kuliah. Pers. (2.7) merupakan penjumlahan slot waktu dosen mengampu mata kuliah dalam sehari. Pers. (2.8) memastikan bahwa setiap dosen hanya mengampu satu mata kuliah tiap satu slot waktu. Pers. (2.9) mencegah mata kuliah yang dijadwalkan pada satu hari menggunakan slot waktu yang tersedia melebihi jumlah kelas yang tersedia. Pers. (2.10) memastikan hanya satu dosen yang mengampu satu mata kuliah.

Pers. (2.11) memastikan bahwa dosen tidak boleh mengampu mata kuliah yang tidak dapat mereka ampu. Pers. (2.12) menghitung jumlah mata kuliah yang diampu oleh dosen. Pers. (2.13) menentukan jumlah mata kuliah yang diampu dosen setiap harinya. Pers. (2.14) - (2.17) merupakan konstrain atau batasan dengan nilai 0-1 untuk variabel keputusan $X_{i j l m}, Y_{i j l}$, $U_{i j l m}$, dan $P_{i j}$. Pers. (2.18) - (2.19) menentukan agar nilai $L_{i}$ dan $V_{i}$ tidak negatif.

\section{Metodologi}

\subsection{Alat dan Bahan Penelitian}

Alat yang digunakan dalam penelitian ini diantaranya: perangkat keras berupa Laptop Asus Prosesor Intel® Core ${ }^{\mathrm{TM}} \mathrm{i} 3-3217 \mathrm{U}$ CPU @ $1.80 \mathrm{GHz}$ 1.70GHz, RAM 2.00 GB, Hardisk 500 GB dan perangkat lunak yang digunakan adalah Microsoft Windows 8 ultimate (32-bit) dan Matlab 2012a (32bit).

Bahan yang digunakan pada penelitian ini adalah data program studi, data dosen, data mahasiswa aktif, data mata kuliah, data ruang kelas serta kapasistas, data jadwal semester aktif, dan data hari serta waktu periode yang digunakan untuk perkuliahan. Data tersebut diperoleh dari Fakultas Teknologi Industri Unissula semester genap tahun ajaran 2015/2016. Data yang terlibat dalam penelitian ini terdiri dari data tiga program studi.

\subsection{Prosedur Penelitian}

Prosedur penelitian ini diawali dengan melakukan identifikasi masalah, analisis kebutuhan sistem, pengujian metode yang dipilih, membandingkan hasil dengan metode lain. Hasil akhir penelitian ini adalah penjadwalan mata kuliah pada perguruan tinggi. 
Identifikasi masalah dengan permasalahan penjadwalan yang dihadapi yaitu, TACS (teacher assignment course scheduling) merupakan penugasan dosen pada mata kuliah untuk kemudian dialokasikan ke slot waktu dan ruang yang tersedia. Dalam penugasan dosen ke mata kuliah yang akan diampu melibatkan penguasaan dosen terhadap mata kuliah, dosen tidak dapat ditugaskan pada mata kuliah yang tidak dikuasai secara materi. Selanjutnya adalah alokasi mata kuliah dengan dosen pengampu pada slot waktu dan ruang yang tersedia. Permasalahan ini melibatkan bentrok dosen dalam slot waktu.

Agar penelitian yang dilakukan lebih terarah maka dilakukan langkah-langkah dalam prosedur penelitian, prosedur penelitian yang dilakukan dapat ditunjukkan pada Gambar 2

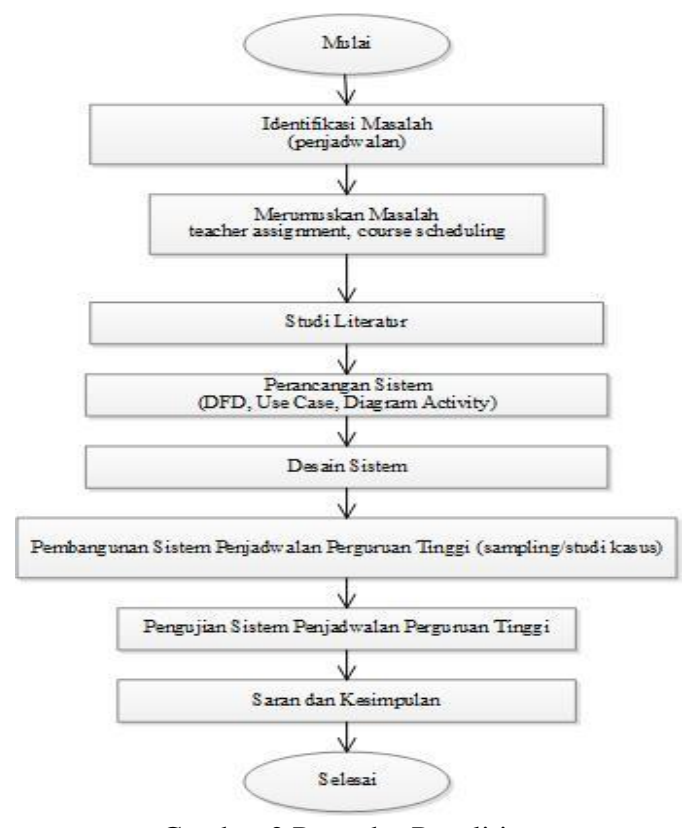

Gambar 2 Prosedur Penelitian

Penjelasan tahapan prosedur penelitian:

a. Tahap Perencanaan

Tahapan ini menjelaskan tujuan utama dari penelitian yang akan dilaksanakan.

b. Identifikasi Masalah

Merupakan tahapan dalam mengenali permasalahan yang dihadapi mengenai penugasan dosen pada mata kuliah yang diampu. Mata kuliah yang telah memiliki dosen pengampu untuk kemudian diplotkan pada slot waktu yang tersedia.

c. Studi Literatur

Setelah mengetahui permaslahan yang dihadapi dilakukan studi literature mengenai permasalahan tersebut. Studi literatur dilakukan dengan melibatkan jurnal dan buku yang berkaitan serta melakukan analisa kepada pihak-pihak yang berhubungan dengan sistem penjadwalan di Universitas.

d. Pembangunan Sistem
Tahapan berikutnya adalah melakukan pembangunan sistem yang terdiri dari langkahlangkah perancangan sistem, desain sistem, pembangunan sistem dan pengujian sistem yang telah dibangun.

d. Saran Kesimpulan

Tahap terakhir adalah memberi kesimpulan atas sistem yang telah dibangun dengan metode yang digunakan mengenai efisiensi metode apakah telah tepat digunakan untuk mengembangkan optimasi penjadwalan mata kuliah pada perguruan tinggi.

\subsection{Kerangka Sistem Informasi}

Kerangka sistem informasi yang akan dibangun terlihat pada Gambar 3 dengan input berupa data-data yang dibutuhkan. Data yang dibutuhkan berupa data dosen, data mata kuliah, data timeslot dan data kurikulum. Pembuatan sistem melibatkan hard constraint dan soft constraint. Hard constraint yang terlibat adalah maksimum beban kerja dosen, jumlah ruang yang tersedia dan jumlah waktu periode yang tersedia. Soft constraint yang terlibat adalah preferensi dosen untuk mengajar mata kuliah tertentu, maksimum jumlah dosen yang dapat mengajar mata kuliah tertentu, minimum jumlah dosen yang dapat mengajar mata kuliah tertentu, dan preferensi dosen mengajar mata kuliah tertentu dalam waktu periode tertetu. Data input kemudian diolah sesuai ketentuan dengan menggunakan metode simulated annealing untuk optimasi baik proses maupun hasil.

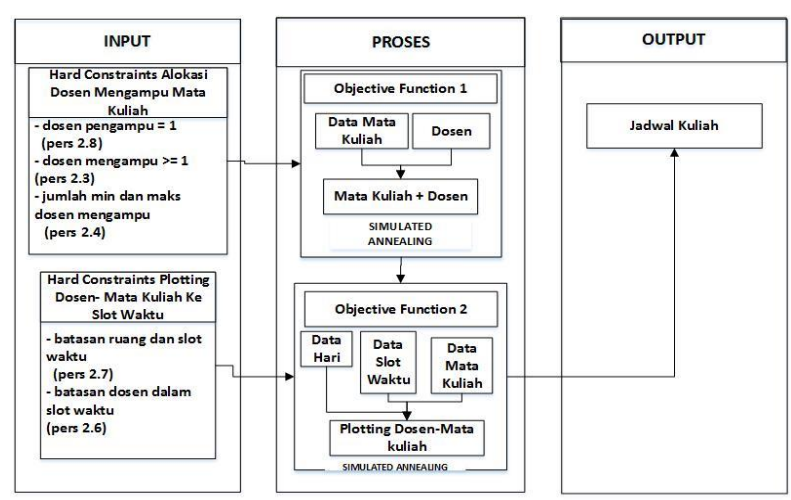

Gambar 3 . Kerangka sistem informasi

\section{Hasil dan Pembahasan}

\subsection{Pengujian Sistem Informasi Penjadwalan Kuliah}

Pada Gambar 4 menunjukkan distribusi mata kuliah pada dosen pengampu. Dengan jumlah mata kuliah sebanyak 152 didistribusikan pada 52 dosen sesuai dengan bidang penguasaan materi. Data mata kuliah dan dosen tersedia dalam bentuk excel, dimana terdapat indexing dosen pengampu dalam penguasaan materi. Data mata kuliah disertai jumlah sks dan dosen pengampu. Dosen ditugaskan pada mata kuliah dengan berbagai batasan yaitu jumlah minimum dan maksimum dosen dapat mengampu mata kuliah dan penguasaan mata kuliah oleh dosen. Antarmuka yang 
ditunjukkan menampilkan nama mata kuliah, kode mata kuliah, jumlah sks dan dosen pengampu.

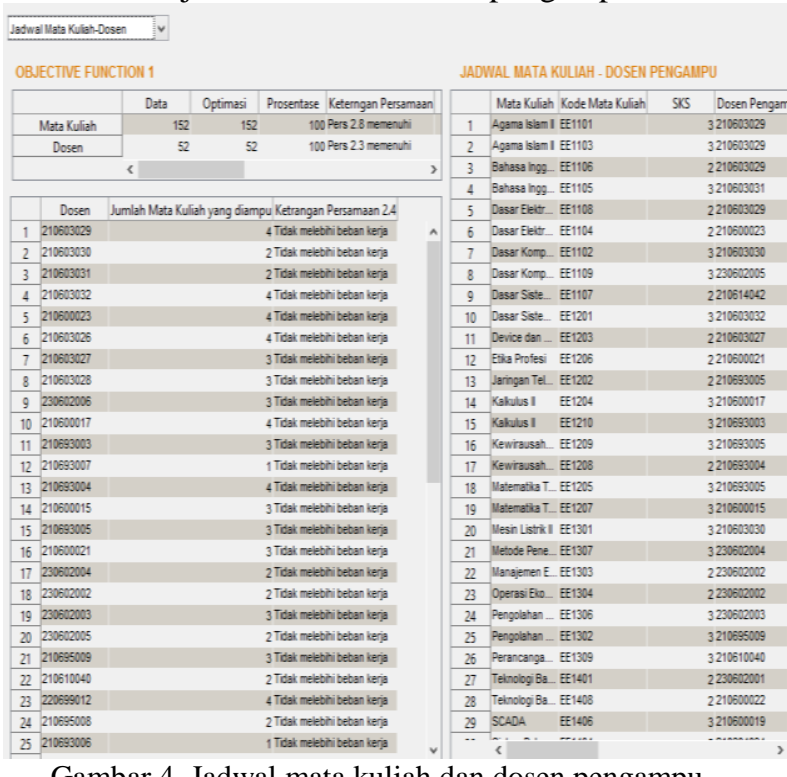

Gambar 4. Jadwal mata kuliah dan dosen pengampu

Jadwal dosen dan waktu slot pada Gambar 5 menunjukkan distribusi mata kuliah dengan dosen pengampu pada waktu periode, hari dan ruang kelas yang tersedia.Dengan jumlah mata kuliah sebanyak 152 dan slot (jumlah waktu periode $\mathrm{X}$ jumlah hari $\mathrm{X}$ jumlah ruang) sebanyak 450 slot terdapat 129 mata kuliah dengan sks yang sesuai mendapat plot pada slot yang tersedia. Mata kuliah menempati slot waktu sesuai dengan jumlah sks, jumlah sks yang digunakan sesuai data pada studi kasus adalah 3 atau 2. Untuk setiap sks adalah 50 menit, dan dalam 1 hari terdapat 10 waktu periode yang berarti 500 menit dalam sehari dan waktu istirahat pukul $12.00-13.00$ tidak digunakan dalam plotting mata kuliah. Waktu periode dimulai dari pukul 07.00 untuk periode pertama dan periode terakhir selesai pukul 16.20. Hari aktif yang digunakan adalah hari senin hingga hari jumat dengan ketersediaan ruang kelas dalam sehari adalah 9. Ruang kelas yang digunakan adalah ruang kelas umum yang dapat digunakan untuk perkuliahan biasa dan tersedia sepanjang slot waktu.

\subsection{Hasil Pengujian Sistem Informasi Penjadwalan Kuliah}

Hasil pengujian pengujian persamaan baik objective function dan hard constraint. Objective function 1 berfungsi untuk melakukan penugasan dosen pada mata kuliah. Dalam penugasan dosen pada mata kuliah melibatkan tiga batasan (hard constraints) yaitu membatasi jumlah mata kuliah yang dapat diampu oleh dosen paling tidak mengampu satu mata kuliah (pers 2.5), memastikan hanya satu dosen yang mengampu satu mata kuliah (pers 2.10) dan batasan jumlah minimum dan maksimum dosen yang mengampu mata kuliah (pers 2.6).

Pada Gambar 6 pada tabel pertama baris pertama terlihat bahwa mata kuliah tepat diampu oleh satu dosen berdasarkan hasil optimasi dengan jumlah yang sama dengan data mentah (152). Data ini melakukan pengujian persamaan 2.10 memastikan hanya satu dosen yang mengampu satu mata kuliah.Sedangkan pada tabel pertama baris kedua melakukan pengujian terhadap persamaan 2.5 dimana satu dosen paling tidak mengampu satu mata kuliah. Pada tabel kedua melakukan pengujian terhadap persamaan 2.6 yaitu dosen memiliki jumlah minimum dan maksimum jumlah mata kuliah yang diampu

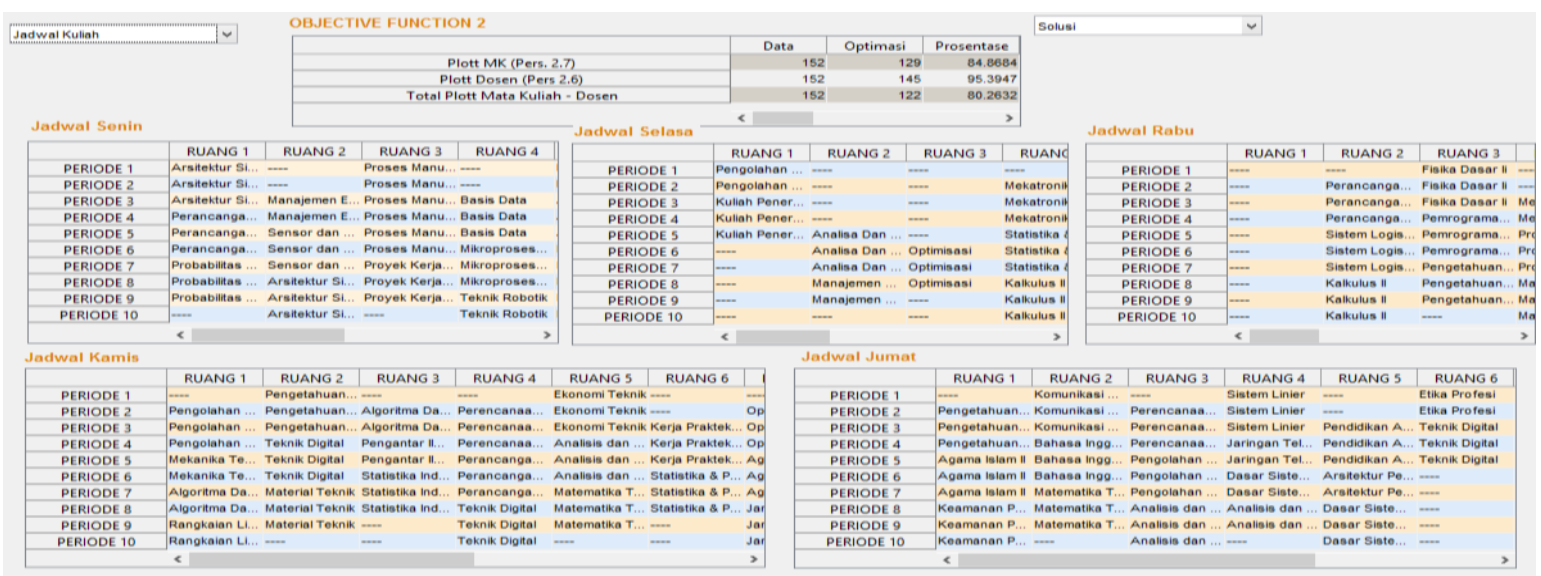

Gambar 5. Jadwal kuliah pada slot waktu 


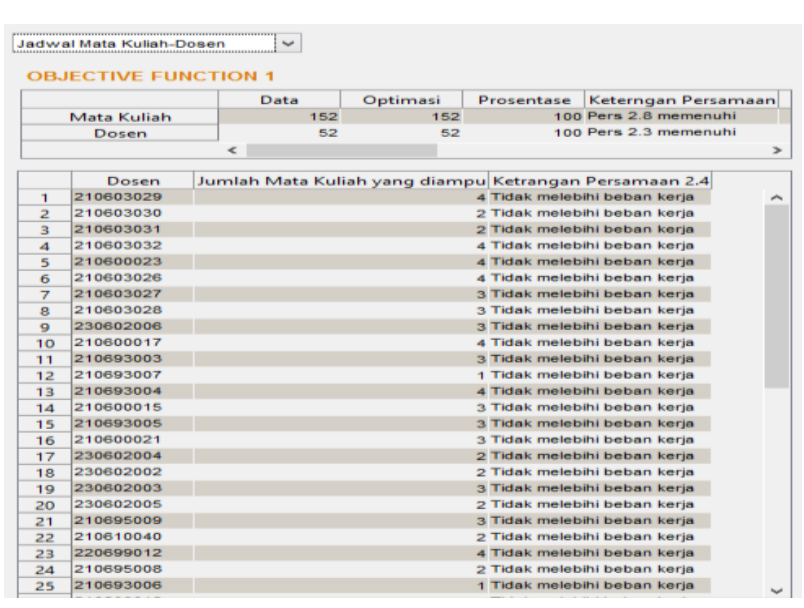

Gambar 6. Optimasi data dosen dan mata kuliah

Pada Tabel 1 menunjukkan parameter yang digunakan dalam persamaan objective function 1 . Total iterasi menunjukan jumlah perulangan dalam pencarian dosen pengampu untuk mata kuliah yang dapat diampu. Temperature awal menunjukan ruang pencarian yaitu sebanyak jumlah data yang akan dioptimasi. Faktor pendingin menunjukkan pengali pada sekali iterasi pencarian solusi. Temperatur akhir menunjukkan kondisi data setelah dioptimasi.

\section{Tabel 2. Parameter Objective Function 1}

\begin{tabular}{lc}
\hline Parameter & Nilai \\
\hline Total iterasi & $|I| x|J|$ \\
Temperatur awal $T_{0}$ & {$[1,152]$} \\
Cooling factor $\alpha$ & $\{0.1\}$ \\
Temperatur akhir $T_{n}$ & 0 \\
\hline
\end{tabular}

Pengujian objective function 2 pada persamaan objective function 2 menghasilkan jadwal dosen dan mata kuliah yang diampu. Setelah jadwal dosen dan mata kuliah diketahui langkah selanjutnya adalah menempatkan (plotting) jadwal dosen dan mata kuliah pada slot waktu dan ruang yang tersedia. Slot waktu terdiri dari jumlah hari dan periode yang tersedia. Dalam penempatan jadwal dosen dan mata kuliah melibatkan dua batasan (hard constraints) yaitu mencegah mata kuliah yang dijadwalkan pada satu hari menggunakan slot waktu yang tersedia melebihi jumlah kelas yang tersedia (pers 2.9), dan memastikan bahwa setiap dosen hanya mengampu satu mata kuliah tiap satu slot waktu (pers 2.8).

152 mata kuliah dapat dialokasikan sebanyak 129 mata kuliah atau 84,8684\%. Hal ini berarti terdapat 23 mata kuliah tidak dapat plotting pada slot waktu yang tersedia. Pada baris kedua menunjukkan kondisi bentrok dosen yang mengampu mata kuliah. Terlihat bahwa terdapat sebanyak 145 mata kuliah dimana dosen pengampu mata kuliah yang bersangkutan tidak mengalami bentrok waktu periode yang tersedia atau sebanyak 95,3947. Hal ini berarti terdapat 7 mata kuliah dengan dosen pengampu yang mengalami bentrok. Dari jumlah mata kuliah yang tidak mendapat plot slot waktu dan mata kuliah dengan dosen yang mengalami bentrok maka didapat jumlah seluruh mata kuliah yang tidak dapat mendapat plot pada slot waktu yaitu sebanyak 30 mata kuliah atau setara dengan $80,2632 \%$.

OBJECTIVE FUNCTION 2
\begin{tabular}{|c|r|rr|r|}
\hline & Data & Optimasi & Prosentase \\
\hline Plott MK (Pers. 2.7) & 152 & 129 & 84.8684 \\
\hline Plott Dosen (Pers 2.6) & 152 & 145 & 95.3947 \\
\hline Total Plott Mata Kuliah - Dosen & 152 & 122 & 80.2632 \\
\hline Gambar 7. Optimasi jadwal dosen-matakuliah pada slot & < & & &
\end{tabular}

Gambar 7. Optimasi jadwal dosen-matakuliah pada slot waktu

Pada Gambar 7 pada baris pertama terlihat bahwa plotting mata kuliah pada slot waktu yang tersedia dari

Tabel 2 menunjukkan parameter yang digunakan dalam persamaan objective function 2. Total iterasi menunjukan jumlah perulangan dalam pencarian dosen pengampu untuk mata kuliah yang dapat diampu. Temperatur awal menunjukan ruang pencarian yaitu sebanyak jumlah data yang akan dioptimasi. Faktor pendingin menunjukkan pengali pada sekali iterasi pencarian solusi. Temperatur akhir menunjukkan kondisi data setelah dioptimasi.

Tabel 2. Parameter Objective Function 2

\begin{tabular}{lc}
\hline Parameter & Nilai \\
\hline Total iterasi & $|I| x|J|$ \\
Temperatur awal $T_{0}$ & {$[1,152]$} \\
Cooling factor $\alpha$ & $\{0.19\}$ \\
Temperatur akhir $T_{n}$ & 30 \\
\hline
\end{tabular}

Tabel 1 menunjukkan parameter yang digunakan dalam persamaan objective function 2. Total iterasi menunjukan jumlah perulangan dalam pencarian dosen pengampu untuk mata kuliah yang dapat diampu. Temperature awal menunjukan ruang pencarian yaitu sebanyak jumlah data yang akan dioptimasi. Faktor pendingin menunjukkan pengali pada sekali iterasi pencarian solusi. Temperatur akhir menunjukkan kondisi data setelah dioptimasi.

Temperatur awal menunjukkan jumlah data yang akan dioptimasi yaitu data mata kuliah dengan dosen pengampu sebanyak 152 data. Faktor pendingin $\alpha$ merupakan faktor pengali pada percobaan diatas menghasilkan nilai 0.19 yang menghasilkan temperatur akhir yaitu 30. Temperatur akhir menunjukkan jumlah mata kuliah yang tidak mendapat plot pada slot waktu yang tersedia. Sedangan analisa metode dengan data sampel dapat ditunjukkan pada Tabel 3. 
Tabel 3. Uji coba metode dengan data sampel

\begin{tabular}{|c|c|c|c|c|c|c|c|c|c|c|c|c|c|c|c|c|c|c|c|}
\hline \multirow[t]{5}{*}{ No } & \multicolumn{9}{|c|}{ Objective Function 1} & \multicolumn{10}{|c|}{ Objective Function 2} \\
\hline & \multicolumn{6}{|c|}{ Dataset } & \multicolumn{3}{|c|}{ SA } & \multicolumn{7}{|c|}{ dataset } & \multicolumn{3}{|c|}{ SA } \\
\hline & \multirow{2}{*}{\multicolumn{2}{|c|}{ Data }} & \multirow{2}{*}{\multicolumn{2}{|c|}{ Optimasi }} & \multirow{2}{*}{\multicolumn{2}{|c|}{ (\%) }} & \multirow[t]{3}{*}{$T_{0}$} & \multirow[t]{3}{*}{$\alpha$} & \multirow[t]{3}{*}{$T_{n}$} & \multirow{2}{*}{\multicolumn{3}{|c|}{ Data }} & \multirow{2}{*}{\multicolumn{3}{|c|}{$\begin{array}{c}\text { Optimasi } \\
\text { Plotting slot waktu }\end{array}$}} & \multirow[t]{2}{*}{ (\%) } & \multirow[t]{3}{*}{$T_{0}$} & \multirow[t]{3}{*}{$\alpha$} & \multirow[t]{3}{*}{$T_{n}$} \\
\hline & & & & & & & & & & & & & & & & & & & \\
\hline & 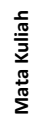 & 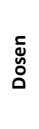 & 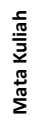 & Фัّ & 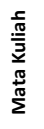 & 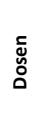 & & & & 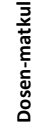 & 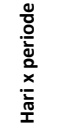 & 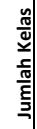 & 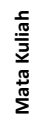 & 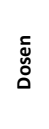 & 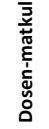 & 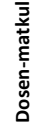 & & & \\
\hline 1. & 152 & 52 & 152 & 52 & 100 & 100 & {$[1,152]$} & $\{0.1\}$ & 0 & 152 & $5 \times 10$ & 9 & 129 & 149 & 126 & $\begin{array}{l}82.8 \\
9\end{array}$ & {$[1,152]$} & $\{0.82\}$ & 26 \\
\hline 2. & 10 & 10 & 10 & 7 & 100 & 70 & {$[1,10]$} & $\{0.1\}$ & 0 & 10 & $5 \times 10$ & 9 & 8 & 9 & 7 & 70 & {$[1,10]$} & $\{0.7\}$ & 3 \\
\hline 3. & 10 & 10 & 10 & 7 & 100 & 70 & {$[1,10]$} & $\{0.1\}$ & 0 & 10 & $5 \times 5$ & 9 & 7 & 9 & 6 & 60 & {$[1,10]$} & $\{0.6\}$ & 4 \\
\hline 4. & 10 & 10 & 10 & 7 & 100 & 70 & {$[1,10]$} & $\{0.1\}$ & 0 & 10 & $5 \times 10$ & 2 & 10 & 9 & 9 & 90 & {$[1,10]$} & $\{0.9\}$ & 1 \\
\hline 5. & 10 & 10 & 10 & 7 & 100 & 70 & {$[1,10]$} & $\{0.1\}$ & 0 & 10 & $5 \times 5$ & 2 & 7 & 9 & 6 & 60 & {$[1,10]$} & $\{0.6\}$ & 4 \\
\hline 6. & 10 & 5 & 10 & 5 & 100 & 100 & {$[1,10]$} & $\{0.1\}$ & 0 & 10 & $5 \times 10$ & 9 & 9 & 9 & 8 & 80 & {$[1,10]$} & $\{0.8\}$ & 2 \\
\hline 7. & 10 & 5 & 10 & 5 & 100 & 100 & {$[1,10]$} & $\{0.1\}$ & 0 & 10 & $5 \times 5$ & 9 & 9 & 9 & 8 & 80 & {$[1,10]$} & $\{0.8\}$ & 2 \\
\hline 8. & 10 & 5 & 10 & 5 & 100 & 100 & {$[1,10]$} & $\{0.1\}$ & 0 & 10 & $5 \times 10$ & 2 & 8 & 9 & 7 & 70 & {$[1,10]$} & $\{0,7\}$ & 3 \\
\hline 9. & 10 & 5 & 10 & 5 & 100 & 100 & {$[1,10]$} & $\{0.1\}$ & 0 & 10 & $5 \times 5$ & 2 & 7 & 9 & 6 & 60 & {$[1,10]$} & $\{0.6\}$ & 4 \\
\hline 10. & 5 & 10 & 5 & 5 & 100 & 50 & {$[1,5]$} & $\{0.1\}$ & 0 & 5 & $5 \times 10$ & 9 & 4 & 5 & 4 & 80 & {$[1,5]$} & $\{0.4\}$ & 1 \\
\hline 11. & 5 & 10 & 5 & 5 & 100 & 50 & {$[1,5]$} & $\{0.1\}$ & 0 & 5 & $5 \times 5$ & 9 & 4 & 5 & 4 & 80 & {$[1,5]$} & $\{0.4\}$ & 1 \\
\hline 12. & 5 & 10 & 5 & 5 & 100 & 50 & {$[1,5]$} & $\{0.1\}$ & 0 & 5 & $5 \times 10$ & 2 & 4 & 5 & 4 & 80 & {$[1,5]$} & $\{0.4\}$ & 1 \\
\hline 13. & 5 & 10 & 5 & 5 & 100 & 50 & {$[1,5]$} & $\{0.1\}$ & 0 & 5 & $5 \times 10$ & 2 & 4 & 5 & 4 & 80 & {$[1,5]$} & $\{0.4\}$ & 1 \\
\hline
\end{tabular}

Tabel 3 menunjukkan uji coba metode pada beberapa variasi data. Data utama berupa data mata kuliah dan data dosen yang digunakan bervariasi dengan berbagai perbandingan. Variasi pertama adalah perbandingan data mata kuliah dengan data dosen 1:1. Dari percobaan untuk objective function 1 terlihat bahwa seluruh data baik mata kuliah dapat teralokasi $100 \%$ sedangkan data dosen sebanyak $70 \%$. Temperatur awal adalah $[1,10]$ yang merupakan jumlah mata kuliah yang akan dialokasikan. Memiliki faktor pendingin $\alpha=0,01$. Dengan berbagai variasi sumber daya berupa slot waktu, hari dan ruang kelas didapat bahwa memiliki rata-rata 70 dalam optimasi jadwal kuliah, yang memiliki arti rata-rata sebanyak $70 \%$ dari seluruh data yang harus dialokasikan.

Tabel 4. Analisa dengan variasi data sampel

\begin{tabular}{|c|c|c|c|c|c|c|c|c|c|c|c|}
\hline \multirow[t]{2}{*}{ No } & \multicolumn{4}{|c|}{ Dataset } & \multicolumn{6}{|c|}{ Optimasi SA } & \multirow[t]{2}{*}{ Kesimpulan-Solusi } \\
\hline & 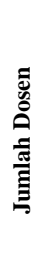 & 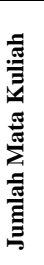 & 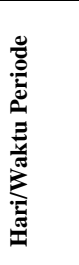 & 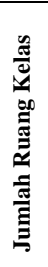 & 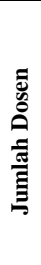 & 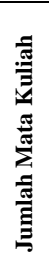 & 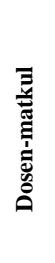 & $\begin{array}{l}\text { Plo } \\
\text { slot }\end{array}$ & 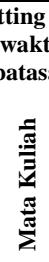 & 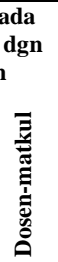 & \\
\hline 1. & 10 & 10 & $5 \times 10$ & 9 & 7 & 10 & 10 & 9 & 8 & 7 & $\begin{array}{l}\text { - Dengan jumlah mata kuliah dan dosen yang sama, dimana kemampuan dosen dalam } \\
\text { mengampu mata kuliah satu dan atau lebih maka ada dosen yang tidak dapat plot } \\
\text { mata kuliah. } \\
\text { - Menambah slot waktu dalam sehari } \\
\text { - Solusi untuk sisa mata kuliah yang tidak dapat diplotkan adalah meletakkan pada } \\
\text { slot waktu yang kosong }\end{array}$ \\
\hline 2. & 10 & 10 & $5 \times 5$ & 9 & 7 & 10 & 10 & 9 & 7 & 6 & $\begin{array}{l}\text { - Menambah slot waktu dalam sehari } \\
\text { - Solusi untuk sisa mata kuliah yang tidak dapat diplotkan adalah meletakkan pada } \\
\text { slot waktu yang kosong }\end{array}$ \\
\hline 3. & 10 & 10 & $5 \times 10$ & 2 & 7 & 10 & 10 & 9 & 10 & 9 & $\begin{array}{l}\text { - Solusi untuk sisa mata kuliah yang tidak dapat diplotkan adalah meletakkan pada } \\
\text { slot waktu yang kosong }\end{array}$ \\
\hline
\end{tabular}

Variasi kedua adalah perbandingan data mata kuliah dengan data dosen 2:1. Untuk objective function 1 didapatkan bahwa seluruh data dosen dan data mata kuliah teralokasikan sebanyak $100 \%$. Dengan variasi jumlah waktu periode, hari dan jumlah kelas maka didapat rata-rata alokasi mata kuliah ke slot yang tersedia adalah 72,5 yang memiliki arti sebanyak $72,5 \%$ data mata kuliah dapat ditempatkan pada slot yang tersedia.

Untuk variasi ketiga adalah perbandingan data mata kuliah dengan data dosen 1:2. Data mata kuliah $100 \%$ dapat dialokasikan sedang data dosen sebanyak $50 \%$. Dengan variasi jumlah waktu periode, hari dan jumlah kelas maka didapat rata-rata alokasi mata kuliah ke slot yang tersedia adalah 80 yang memiliki arti sebanyak $80 \%$ data mata kuliah dapat ditempatkan pada slot yang tersedia. 


\begin{tabular}{|c|c|c|c|c|c|c|c|c|c|c|c|}
\hline \multirow[t]{2}{*}{ No } & \multicolumn{4}{|c|}{ Dataset } & \multicolumn{6}{|c|}{ Optimasi SA } & \multirow[t]{2}{*}{ Kesimpulan-Solusi } \\
\hline & 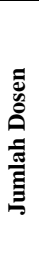 & 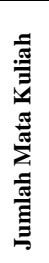 & 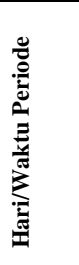 & 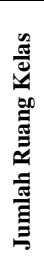 & 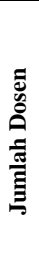 & 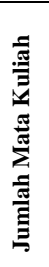 & 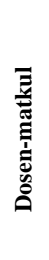 & $\begin{array}{r}\text { Pl } \\
\text { slo }\end{array}$ & 运 & 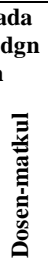 & \\
\hline 4. & 10 & 10 & $5 \times 10$ & 2 & 7 & 10 & 10 & 9 & 7 & 6 & $\begin{array}{l}\text { - } \text { Menambah slot waktu dalam sehari } \\
\text { - Solusi untuk sisa mata kuliah yang tidak dapat diplotkan adalah meletakkan pada } \\
\text { slot waktu yang kosong dan menambah slot waktu dan ruang }\end{array}$ \\
\hline 5. & 5 & 10 & $5 \times 10$ & 9 & 5 & 10 & 10 & 9 & 9 & 8 & $\begin{array}{l}\text { Dengan jumlah mata kuliah lebih banyak dari jumlah dosen, maka semua mata } \\
\text { kuliah dapat terdistribusi ke seluruh dosen yang tersedia } \\
\text { - Solusi agar semua mata kuliah dapat terdistribusi adalah menambah jumlah dosen } \\
\text { - Solusi untuk sisa mata kuliah yang tidak dapat diplotkan adalah meletakkan pada } \\
\text { slot waktu yang kosong }\end{array}$ \\
\hline 6. & 5 & 10 & $5 \times 5$ & 9 & 5 & 10 & 10 & 9 & 9 & 8 & $\begin{array}{l}\text { Dengan jumlah mata kuliah lebih banyak dari jumlah dosen, maka semua mata } \\
\text { kuliah dapat terdistribusi ke seluruh dosen yang tersedia } \\
\text { - Menambah slot waktu dalam sehari } \\
\text { - Solusi untuk sisa mata kuliah yang tidak dapat diplotkan adalah meletakkan pada } \\
\text { slot waktu yang kosong }\end{array}$ \\
\hline 7. & 5 & 10 & $5 \times 10$ & 2 & 5 & 10 & 10 & 9 & 8 & 7 & $\begin{array}{l}\text { Dengan jumlah mata kuliah lebih banyak dari jumlah dosen, maka semua mata } \\
\text { kuliah dapat terdistribusi ke seluruh dosen yang tersedia } \\
\text { - Solusi untuk sisa mata kuliah yang tidak dapat diplotkan adalah meletakkan pada } \\
\text { slot waktu yang kosong }\end{array}$ \\
\hline 8. & 5 & 10 & $5 \times 5$ & 2 & 5 & 10 & 10 & 9 & 7 & 6 & $\begin{array}{l}\text { Dengan jumlah mata kuliah lebih banyak dari jumlah dosen, maka semua mata } \\
\text { kuliah dapat terdistribusi ke seluruh dosen yang tersedia } \\
\text { - Solusi untuk sisa mata kuliah yang tidak dapat diplotkan adalah meletakkan pada } \\
\text { slot waktu yang kosong } \\
\text { - menambah slot waktu dan ruang }\end{array}$ \\
\hline 9. & 10 & 5 & $5 \times 10$ & 9 & 5 & 5 & 5 & 5 & 4 & 4 & $\begin{array}{l}\text { Dengan jumlah mata kuliah lebih sedikit dari jumlah dosen yang tersedia, maka } \\
\text { distribusi dosen yang mengampu mata kuliah adalah sebanyak jumlah mata kuliah. } \\
\text { - Solusi untuk sisa mata kuliah yang tidak dapat diplotkan adalah meletakkan pada } \\
\text { slot waktu yang kosong }\end{array}$ \\
\hline 10. & 10 & 5 & $5 \times 5$ & 9 & 5 & 5 & 5 & 5 & 4 & 4 & $\begin{array}{l}\text { Dengan jumlah mata kuliah lebih sedikit dari jumlah dosen yang tersedia, maka } \\
\text { distribusi dosen yang mengampu mata kuliah adalah sebanyak jumlah mata kuliah. } \\
\text { - Solusi untuk sisa mata kuliah yang tidak dapat diplotkan adalah meletakkan pada } \\
\text { slot waktu yang kosong }\end{array}$ \\
\hline 11. & 10 & 5 & $5 \times 10$ & 2 & 5 & 5 & 5 & 5 & 4 & 4 & $\begin{array}{l}\text { Dengan jumlah mata kuliah lebih sedikit dari jumlah dosen yang tersedia, maka } \\
\text { distribusi dosen yang mengampu mata kuliah adalah sebanyak jumlah mata kuliah. } \\
\text { - Solusi untuk sisa mata kuliah yang tidak dapat diplotkan adalah meletakkan pada } \\
\text { slot waktu yang kosong }\end{array}$ \\
\hline 12. & 10 & 5 & $5 \times 5$ & 2 & 5 & 5 & 5 & 5 & 4 & 4 & $\begin{array}{l}\text { Dengan jumlah mata kuliah lebih sedikit dari jumlah dosen yang tersedia, maka } \\
\text { distribusi dosen yang mengampu mata kuliah adalah sebanyak jumlah mata kuliah. } \\
\text { - Solusi untuk sisa mata kuliah yang tidak dapat diplotkan adalah meletakkan pada } \\
\text { slot waktu yang kosong }\end{array}$ \\
\hline
\end{tabular}

Dari percobaan yang telah dilakukan variasi perbadingan data dosen dengan mata kuliah dengan perbadingan 1:1, 1:2 dan 2:1 memiliki hasil optimal pada data dengan perbandingan 2:1. Dengan jumlah slot waktu dan ruang kelas yang bervariasi prosentase optimasi untuk jadwal kuliah memiliki nilai yang stabil yaitu $80 \%$. Dengan data dosen yang lebih banyak maka penugasan dosen ke mata kuliah dapat lebih optimal dengan mempertimbangkan batasanbatasan berupa jumlah maksimum dosen mengampu mata kuliah. Dari percobaan dengan data real dapat diketahui perbandingan jumlah mata kuliah yang lebih banyak dari dosen dengan nilai 1:3 masih didapatkan hasil optimal (100\%) untuk penugasan dosen ke mata kuliah.

Untuk objective function 1, hasil yang optimal didapatkan dengan memperhatikan keseimbangan jumlah dosen yang tersedia untuk mengampu mata kuliah. Apabila jumlah dosen terlalu sedikit dibanding dengan jumlah mata kuliah, maka pelanggaran terhadap batasan jumlah maksimum dosen mengampu mata kuliah akan terjadi. Untuk objective function 2 , hasil yang optimal didapat apabila jumlah slot waktu yang tersedia cukup untuk penempatan mata kuliah. Beberapa solusi yang ditawarkan adalah sisa mata kuliah yang tidak dapat diplotkan adalah meletakkan pada slot waktu yang kosong, penambahan slot waktu dan penambahan ruang kelas yang dapat digunakan.

Pada Tabel 5 dapat ditunjukkan hasil percobaan dengan SA. Analisa penyimpangan hasil percobaan metode SA pada Percobaan dengan data real dengan menggunakan sebanyak 152 data mata kuliah dan 52 data dosen menghasilkan variasi terhadap prosentase optimasi. Dari percobaan yang dilakukan sebanyak 20 kali seperti yang terlihat pada tabel 5 dilakukan perhitungan simpangan baku atau standar deviasi. Standar deviasi dari percobaan didapatkan nilai 3.931509 .

$$
s=\sqrt{\frac{1}{n} \sum f_{i}\left(x_{i}-x\right)^{2}}=1.982803
$$

Dari hasil perhitungan didapat nilai standar deviasi sebesar 1.982803, nilai ini menunjukkan keberagaman hasil percobaan dengan beberapa data sampel dengan nilai berkisar 3 merupakan nilai yang tidak begitu besar sehingga dapat disimpulkan bahwa metode yang 
digunakan memiliki kestabilan dalam melakukan optimasi untuk menghasilkan jadwal kuliah.

Tabel 5. Penyimpangan hasil percobaan dengan SA

\begin{tabular}{cccc}
\hline No & $\begin{array}{c}\text { Percobaan } \\
\text { ke- }\end{array}$ & $\begin{array}{c}\text { Jumlah } \\
\text { Data } \\
\text { teroptimasi }\end{array}$ & $\begin{array}{c}\text { Prosentase } \\
\left(X_{i}\right)\end{array}$ \\
\hline 1 & 1 & 118 & 77,63 \\
2 & 2 & 116 & 76,31 \\
3 & 3 & 122 & 80,26 \\
4 & 4 & 113 & 74,34 \\
5 & 5 & 116 & 76,31 \\
6 & 6 & 118 & 77,63 \\
7 & 7 & 116 & 76,31 \\
8 & 8 & 112 & 73,68 \\
9 & 9 & 118 & 77,63 \\
10 & 10 & 122 & 80,26 \\
11 & 11 & 115 & 75,65 \\
12 & 12 & 119 & 78,28 \\
13 & 13 & 119 & 78,28 \\
\hline 14 & 14 & 121 & 79,60 \\
15 & 15 & 124 & 81,57 \\
16 & 16 & 120 & 78,94 \\
17 & 17 & 122 & 80,26 \\
18 & 18 & 118 & 77,63 \\
19 & 19 & 117 & 76,97 \\
20 & 20 & 119 & 78,28 \\
\hline
\end{tabular}

Hasil pengujian dengan metode solusi Metode SA awal digunakan memiliki rata-rata varian pembuatan jadwal kuliah sebanyak 77.791 hal ini menunjukkan bahwa ada mata kuliah yang tidak mendapat plot pada slot waktu yang tersedia. Pada percobaan dikembangakn metode solusi untuk mengatasi permasalahan ini. Pada langkah metode pertama memungkinkan adanya slot yang kosong dikarenakan beberapa batasan yang digunakan. Metode solusi yang ditawarkan melakukan penggunaan kembali slot-slot yang tidak terpakai untuk mata kuliah yang belum mendapat plot pada slot waktu. Pada tabel 6 menunjukkan beberapa hasil percobaan optimasi data mata kuliah yang tidak mendapat slot pada metode yang pertama.

Metode ini melakukan pengambilan slot yang belum terpakai. Pada percobaan dengan jumlah hari sebanyak 5, waktu periode sebanyak 10 dan ruang kelas sebanyak 9 disimpulkan bahwa untuk mengalokasikan seluruh data mata kuliah memerlukan tambahan waktu periode. Tambahan waktu periode dilakukan setelah periode terakhir dalam sehari. Penambahan waktu periode dianggap lebih efisien dibanding penambahan ruang kelas, karena tidak memerlukan penambahan sumber daya ruang kelas yang mungkin saja memiliki jumlah yang terbatas.

Penambahan waktu periode paling sedikit berjumlah $9 \mathrm{x}$ jumlah sks periode dengan asumsi waktu periode maksimum untuk satu mata kuliah adalah 3 sks atau 3 periode, maka dengan penggunaan 9 ruang kelas penambahan 9 waktu periode dapat diletakan dalam 1 hari kerja. Jumlah penambahan waktu periode terbanyak adalah $15 \mathrm{x}$ jumlah sks, maka diperlukan penambahan 1 hari kerja untuk penempatan mata kuliah.

Tabel 6. Analisa optimasi dengan metode solusi

\begin{tabular}{|c|c|c|c|c|}
\hline \multirow[t]{2}{*}{ No } & \multirow{2}{*}{$\begin{array}{l}\text { Metode SA } \\
\text { Mata Kuliah } \\
\text { tidak } \\
\text { Terplotting }\end{array}$} & \multicolumn{2}{|l|}{ Metode Solusi } & \multirow[t]{2}{*}{ Keterangan } \\
\hline & & $\begin{array}{l}\text { Mata Kuliah } \\
\text { terplotting }\end{array}$ & $\begin{array}{l}\text { Mata Kuliah } \\
\text { tidak } \\
\text { Terplotting }\end{array}$ & \\
\hline 1 & 34 & 25 & 9 & $\begin{array}{l}\text { Membutuhkan } \\
\text { tambahan slot waktu } \\
\text { sebanyak } \\
\text { (9xjumlah_sks) }\end{array}$ \\
\hline 2 & 36 & 19 & 17 & $\begin{array}{l}\text { Membutuhkan } \\
\text { tambahan slot waktu } \\
\text { sebanyak } \\
\text { (17xjumlah_sks) }\end{array}$ \\
\hline 3 & 30 & 21 & 9 & $\begin{array}{l}\text { Membutuhkan } \\
\text { tambahan slot waktu } \\
\text { sebanyak } \\
\text { (9xjumlah_sks) }\end{array}$ \\
\hline 4 & 39 & 22 & 17 & $\begin{array}{l}\text { Membutuhkan } \\
\text { tambahan slot waktu } \\
\text { sebanyak } \\
\text { (17xjumlah_sks) }\end{array}$ \\
\hline 5 & 36 & 21 & 15 & $\begin{array}{l}\text { Membutuhkan } \\
\text { tambahan slot waktu } \\
\text { sebanyak } \\
\text { (15xjumlah_sks) }\end{array}$ \\
\hline 6 & 34 & 25 & 9 & $\begin{array}{l}\text { Membutuhkan } \\
\text { tambahan slot waktu } \\
\text { sebanyak } \\
\text { (9xjumlah_sks) }\end{array}$ \\
\hline 7 & 36 & 19 & 17 & $\begin{array}{l}\text { Membutuhkan } \\
\text { tambahan slot waktu } \\
\text { sebanyak } \\
\text { (17xjumlah_sks) }\end{array}$ \\
\hline 8 & 40 & 24 & 16 & $\begin{array}{l}\text { Membutuhkan } \\
\text { tambahan slot waktu } \\
\text { sebanyak } \\
\text { (16xjumlah_sks) }\end{array}$ \\
\hline 9 & 34 & 16 & 18 & $\begin{array}{l}\text { Membutuhkan } \\
\text { tambahan slot waktu } \\
\text { sebanyak } \\
\text { (18xjumlah_sks) }\end{array}$ \\
\hline 10 & 30 & 19 & 11 & $\begin{array}{l}\text { Membutuhkan } \\
\text { tambahan slot waktu } \\
\text { sebanyak } \\
\text { (11xjumlah_sks) }\end{array}$ \\
\hline 11 & 37 & 22 & 14 & $\begin{array}{l}\text { Membutuhkan } \\
\text { tambahan slot waktu } \\
\text { sebanyak } \\
\text { (14xjumlah_sks) }\end{array}$ \\
\hline 12 & 33 & 19 & 14 & $\begin{array}{l}\text { Membutuhkan } \\
\text { tambahan slot waktu } \\
\text { sebanyak } \\
\text { (14xjumlah_sks) }\end{array}$ \\
\hline 13 & 33 & 14 & 19 & $\begin{array}{l}\text { Membutuhkan } \\
\text { tambahan slot waktu } \\
\text { sebanyak } \\
\text { (19xjumlah_sks) }\end{array}$ \\
\hline 14 & 31 & 21 & 10 & $\begin{array}{l}\text { Membutuhkan } \\
\text { tambahan slot waktu } \\
\text { sebanyak } \\
\text { (17xjumlah_sks) }\end{array}$ \\
\hline 15 & 28 & 18 & 10 & $\begin{array}{l}\text { Membutuhkan } \\
\text { tambahan slot waktu } \\
\text { sebanyak } \\
\text { (17xjumlah_sks) }\end{array}$ \\
\hline 16 & 32 & 19 & 13 & $\begin{array}{l}\text { Membutuhkan } \\
\text { tambahan slot waktu } \\
\text { sebanyak } \\
\text { (17xjumlah_sks) }\end{array}$ \\
\hline 17 & 30 & 19 & 11 & $\begin{array}{l}\text { Membutuhkan } \\
\text { tambahan slot waktu } \\
\text { sebanyak } \\
\text { (17xjumlah_sks) }\end{array}$ \\
\hline 18 & 34 & 11 & 13 & $\begin{array}{l}\text { Membutuhkan } \\
\text { tambahan slot waktu } \\
\text { sebanyak } \\
\text { (17xjumlah_sks) }\end{array}$ \\
\hline 19 & 35 & 21 & 14 & $\begin{array}{l}\text { Membutuhkan } \\
\text { tambahan slot waktu } \\
\text { sebanyak } \\
\text { (14xjumlah_sks) }\end{array}$ \\
\hline 20 & 33 & 21 & 12 & $\begin{array}{l}\text { Membutuhkan } \\
\text { tambahan slot waktu } \\
\text { sebanyak } \\
\text { (12xjumlah_sks) }\end{array}$ \\
\hline
\end{tabular}




\section{Kesimpulan}

Berdasarkan hasil penelitian optimasi jadwal kuliah dengan menggunakan metode simulated annealing diperoleh kesimpulan sebagai berikut :

1. Dari hasil penelitian optimasi jadwal kuliah dengan menggunakan Simulated Annealing dengan menggunakan data mata kuliah sebanyak 152, data dosen sebanyak 52, data hari sebanyak 5 , data waktu periode per hari sebanyak 10 dan data ruang sebanyak 9 diperoleh hasil rata-rata varian alokasi mata kuliah pada slot waktu yang tersedia adalah 77.791 dengan standar deviasi sebesar 1.982803

2. Pada hasil penelitian yang dilakukan dengan menggunakan beberapa variasi data diperoleh jumlah perbadingan ideal untuk hasil optimasi yang maksimal adalah jumlah mata kuliah dan dosen dengan perbandingan 1:3.

3. Metode solusi yang ditawarkan untuk mendapatkan hasil optimal yaitu penempatan seluruh mata kuliah pada slot waktu dapat dilakukan dengan penggunaan kembali slot waktu yang kosong dan penambahan slot waktu dengan prosentase minimal mata kuliah yang ditempatkan pada slot baru adalah $0.059 \%$ dan prosentase maksimal mata kuliah yang ditempatkan pada slot baru adalah $0.12 \%$.

\section{Daftar Pustaka}

Babei, H., Karimpour, J., Hadidi, A., 2015. A survey of approaches for university course timetabling problem, Computers \& Industrial Engineering 86, 43-59.
Basir, N., Ismail, W., Norwawi,. 2013. A Simulated Annealing for Tahmidi course Timetabling, Procedia Technology 11, $437-445$.

Cacchiani, V., Caprara, A., Roberti, R., Toth, R., 2013. A new lower bound for curriculum-based course timetabling, Computers \& Operations Research 40, 2466-2477.

Chamber, L.D., 1998. Practical Handbook of Genetic Algorithms: Complex Coding Systems, Volume 3, New York: CRC Press.

Chibante, R., 2010. Simulated Annealing Theory with Applications, Rijeka: Sciyo.

Daskalaki, S., Birbas, T., Housos, E., 2004. An integer programming formulation for a case study in university timetabling, European Journal of Operational Research 153, 117-135.

Fong, C.W., Asmuni, H., McCollum, B., McMullan, P., Omatu, S., 2014. A new hybrid imperialist swarm-based optimization algorithm for university timetabling problems, Information Sciences 283, $1-21$.

Gunawan, A., Ng, K.M., Poh, K.L., 2012. A hybridized Lagrangian relaxation and simulated annealing method for the course timetabling problem, Computers\& Operations Research 39, 3074-3088.

Kalivas, J.H., 1995. Adaption of simulated annealing to chemical optimization problems, Elsevier: Amsterdam.

Mu, C.H., Xie, J., Liu, Y., Chen, F., Liu, Y., Jiao, L.C., 2015. Memetic algorithm with simulated annealing strategy and tightnessgreedy optimization for community detection in networks, Applied Soft Computing 34, 485-501.

Yamit, Zulian. 2011. Manajemen Produksi \& Operasi. Yogyakarta: Ekonisia. 